\title{
FUTEBOL NOS ANOS 1930 E 1940: CONSTRUINDO A IDENTIDADE NACIONAL*
}

\author{
Soccer in the 1930's and 1940's: \\ building the national identity
}

Plínio José Labriola de Campos Negreiros**

\begin{abstract}
RESUMO
Este texto apresenta algumas questões acerca do relacionamento entre o futebol e a construção da identidade nacional no Brasil, especificamente a partir dos anos 1930. Para isso, a nossa atenção se volta para dois eventos especiais dentro da história do futebol no Brasil: a Copa de 38 e o Estádio do Pacaembu (1940). Quanto à participação dos brasileiros na Copa do Mundo de 1938, simbolicamente, reforçou-se a idéia de que aquela não era uma mera disputa esportiva. Ao mesmo tempo, este trabalho olha para a construção do estádio do Pacaembu, em São Paulo, enquanto uma obra que sintetiza não apenas a experiência do futebol em São Paulo, mas também as relações desse esporte com o espaço urbano.
\end{abstract}

Palavras-chave: Estádio do Pacaembu, Identidade Nacional, Copa de 1938, Futebol.

\begin{abstract}
This text presents some questions about the relationship between soccer and the construction of Brazil's national identity, specifically the 1930's. With this intention, our attention turns to two special events in Brazilian soccer history: the World Cup of 1938 and the Pacaembu Stadium (1940). Concerning the Brazilian participation in the World Cup of 1938, we show how soccer has been articulated with the Brazilian society. Symbolically, the idea that it was not an only sports competition was reinforced. At the same time, this work consist viewing the construction of the Pacaembu Stadium in São Paulo as a work that not only synthesizes São Paulo's experience with soccer, but also the relation between urban areas and the sport.

Key-words: Pacaembu Stadium, National Identity, World Cup of 1938, Soccer.

* Este artigo trata de algumas questões abordadas na nossa tese de doutorado A nação entra em campo: futebol nos anos 30 e 40. São Paulo, PUC-SP, 1998.

** Doutor em História Social pela PUC-SP. E-mail: plabriola@bol.com.br
\end{abstract}




\section{Introdução}

O Brasil respira futebol. Especialmente na época de disputa de uma Copa do Mundo, os meios de comunicação inundam nossos sentidos com este esporte tão apaixonante. Um clima de unidade nacional é forjado, não deixando imune sequer aqueles que não gostam desse esporte. Ser brasileiro tornou-se sinônimo de torcer pelo selecionado de futebol do país.

Quando as partidas do campeonato mundial passam a ser disputas, uma espécie de ritual ocorre a cada participação do selecionado nacional. Nas horas que antecedem a esses jogos, nas grandes cidades, milhares de pessoas buscam chegar rapidamente a suas casas, sempre com medo de perder algum momento importante. A partida é acompanhada junto aos amigos e vizinhos. Cerveja, rojões e muita comemoração ao final da partida - em caso de vitória completam esse ritual. Não há espaço para as atividades produtivas. Numa verdadeira vigília cívica, o país pára.

Essa paixão do brasileiro pelo futebol - que não se resume ao momento de uma Copa-é um fenômeno cultural que merece menos incredulidade e mais análises. Estas, depois de muita resistência, começaram a ser construídas - ainda que timidamente-em algumas universidades brasileiras. Sem dúvida, ainda há muito a ser feito.

A importância que o futebol conquistou dentro da sociedade brasileira, não permite mais que ele seja ignorado enquanto um objeto para os estudos históricos. Os vínculos que a sociedade brasileira construiu com esse esporte são por demais fortes para que se continue a desqualificar o futebol enquanto uma experiência cultural das mais significativas. A partir do esporte que mais adeptos tem no mundo, é possível conhecer um pouco mais sobre o Brasil.

Neste sentido, tenho como objetivo discutir um momento da História do Brasil que considero fundamental para compreender essa ligação do futebol com a construção de uma identidade nacional. Trata-se dos anos 1930 e 1940, especificamente ao que se refere ao Estado Novo, instante de organização estatal dos esportes brasileiros, com uma atenção especial para o futebol.

Trabalhar com o futebol, durante os anos 1930 e 1940, liga-se ao fato de ter-se uma época de transição no futebol, com a sedimentação de uma organização profissional, ainda que guardando fortes resquícios amadorísticos. ${ }^{1}$

1 O futebol brasileiro contemporâneo enquanto uma junção de uma ordem profissional, no tocante aos jogadores, e amadora, em relação à sua direção, produziu um grande impasse. Esta é a tese central do trabalho de Ronaldo Helal em Passes e impasses - Futebol e cultura de massa no Brasil. Petrópolis: Vozes, 1997. 
Percebe-se nesse período, a preocupação efetiva do Estado brasileiro em produzir a normatização dos esportes, pretendendo atingir a totalidade das organizações esportivas do país. Também, pela primeira vez o poder público no Brasil aproximou-se efetivamente do futebol, procurando retirar desse esporte inúmeros benefícios. ${ }^{2}$

Não como um mero reflexo das transformações que o país foi vivendo, o futebol pode se tornar um referencial possível para se compreender alguns aspectos que marcam o Brasil. Nas rupturas políticas ocorridas neste século de República, em muitas delas, o futebol se antecipou. No processo de popularização desse esporte, por exemplo, a maior parte dos brasileiros começava a conquistar um espaço dentro do futebol, cujo acesso não lhe era permitido. $^{3}$

Também as questões raciais fizeram do futebol um lugar especial de debates, no qual vários preconceitos arraigados foram postos à prova, ainda que não plenamente superados. Graças ao futebol, em grande parte, afloraram discussões acerca do papel do negro dentro da sociedade brasileira. Em muitos momentos, duvidou-se da legitimidade e da capacidade do negro em representar o país através do futebol. Dessa maneira, o deliberado "embranquecimento" do selecionado nacional de futebol deve ser compreendido como parte de um projeto político mais amplo. Ao mesmo tempo, se não concordamos com a concepção do futebol enquanto o democratizador racial brasileiro, não podemos ignorar o seu papel de questionador de uma ordem com resquícios escravocratas.

2 A aproximação do poder público diante do futebol existe desde a introdução deste esporte em fins do século passado. Porém, constituía-se numa relação sem vínculos sistematizados, que dependia do sabor dos acontecimentos. Neste sentido, é possível verificar a presença de autoridades nas tribunas de honra quando da realização de partidas importantes. Ao mesmo tempo, esse poder público, desde o início do século, contribuía com os clubes de várias maneiras, seja como a concessão de um terreno para a construção de uma sede esportiva, seja com a doação de uma taça para ser colocada à disposição de um clube vencedor de um campeonato, entre outras formas. Por outro lado, essas ações não faziam com que o Estado tivesse planos estratégicos em relação ao esporte violento bretão - forma como o futebol era chamado nos anos 10 pela imprensa esportiva de São Paulo. Mais sobre essa questão pode ser verificado em NEGREIROS, Plínio José Labriola de Campos. Resistência e Rendição - A gênese do S. C. Corinthians Paulista e o futebol oficial em São Paulo, 1910-1916. São Paulo, 1992. Dissertação (Mestrado) - Pontifícia Universide Católica de São Paulo.

3 Ao mesmo tempo em que o Estado Oligárquico evitava qualquer tipo de manifestação dos setores populares, daí a "questão social ser caso de polícia", também o futebol era uma prática elitizada, ao menos na sua organização oficial. Porém, lentamente o futebol oficial elitista foi sendo ocupado pelas classes populares, o que fez com que a sua organização passasse por transformações significativas. De certa maneira, é possível afirmar que o futebol recebeu a presença popular antes do que as manifestações políticas. Esta questão pode ser vista em NEGREIROS. op. cit. 
O caráter autoritário que permeia as relações sociais no país também pode ter no futebol um importante ponto de referência. Este esporte, em toda a sua história, padece dos males que assolam a sociedade brasileira. Torcedores e jogadores, as principais personagens dessa manifestação cultural tão rica, são desconsiderados dentro de uma organização que privilegia dirigentes oportunistas, que fazem da especulação de atletas profissionais a sua grande fonte de renda.

Assim, pensar o futebol, principalmente a partir dos anos 1920, com as multidões ocupando cada espaço desse esporte, possibilita compreender as relações que foram estabelecendo-se entre as classes populares e as elites econômicas, culturais e políticas. Quando essas mesmas elites detinham o futebol enquanto um espaço exclusivo, reservavam a esse esporte elogios e tarefas que permitiriam, entre outros pontos, a redenção da nação, em função da construção de uma elite dirigente capaz e de um povo forte. ${ }^{4}$

Quando esse esporte deixa de ser o lugar de encontro de uma elite sempre desvinculada e avessa aos problemas populares -, novos setores sociais se fizeram presentes. Ao mesmo tempo em que o futebol foi perdendo seu caráter branco e elitista, veio o seu desprestígio social. A essas elites só restou desdenhá-lo como uma manifestação da irracionalidade, do atraso, da desordem, da violência, da ausência de caráter educativo. Em última análise, demonstrava-se a incapacidade de o futebol estar nas mãos dos setores populares. Destes só poderiam ser esperados atos inconseqüentes. Não havia como fazer o futebol desaparecer. Portanto, era preciso discipliná-lo, era preciso uma ordenação que viesse de cima e a partir da intervenção do poder público.

A desordem precisava ser substituída pela ordem das elites. Cabia ao futebol, apesar das múltiplas restrições que lhe eram feitas, contribuir para que a construção da nação brasileira se concretizasse. Esse vai ser o novo papel do futebol.

Ao mesmo tempo, o futebol precisava apresentar a sua contribuição para um país que passava, com alguma rapidez, de uma ordem rural para uma urbana-industrial. Essa ligação não poderia ter sido mais feliz. Coube a esse esporte tornar-se uma das atividades mais adequadas às novas exigências que a constituição de uma metrópole apontava. Também outros esportes aponta-

4 A importância da construção de uma elite dirigente competente para o país faz com que o escritor Monteiro Lobato, ainda no início do século, visse no futebol um papel decisivo no sentido de contribuir para essa construção. (BERTOLLI FILHO, Cláudio; MEIHY, José Carlos Sebe Bom. Monteiro Lobato e o futebol: projeto para a elite urbana no começo do século. In: MEIHY, José Carlos Sebe Bom; WITTER, José Sebastião. Futebol e Cultura - Coletânea de Estudos. São Paulo, Convênio IMESP/DAESP, 1982). 
ram nessa direção, mas não com tantos atributos quanto o esporte capaz de seduzir multidões. ${ }^{5}$

Pensar o Brasil a partir do futebol. Esta poderia parecer uma assertiva mecanicista, atribuindo ao também chamado esporte bretão, um significado maior do que ele tem. Na verdade, se nem tudo pode ser analisado via futebol, muitos enigmas brasileiros podem ser desvendados, ao se abordar a história do Brasil por esse viés.

Enfim, compreender a prática do futebol no Brasil, partindo das experiências de São Paulo, garante uma percepção maior das tensões que marcam a constituição da sociedade brasileira.

Ao final dos anos 1930, com o futebol tornado-se uma atividade ainda mais apaixonante, capaz de envolver cada vez mais os brasileiros - entre outros fatores -, é interessante observar como o caráter das obras abordando o esporte mais popular do país passava por significativas transformações. Dois autores, cronistas esportivos, podem ser destacados: Thomaz Mazzoni, de São Paulo e Mário Filho, do Rio de Janeiro. Mazzoni escreveu - nesta década duas obras importantes: O Brasil na Taça do Mundo (1938) e Problemas e Aspectos do Nosso Futebol (1939). Nesses dois trabalhos a tônica era a mesma: o futebol não poderia ser desvinculado dos acontecimentos mais gerais do país; e os esportes, com destaque para o futebol, deveriam estar a serviço da nação. ${ }^{6}$

Como cronista esportivo muito atento às questões de sua época, Thomaz Mazzoni apresenta: Problemas e Aspectos do Nosso Futebol, em 1939. O livro é uma coletânea de artigos publicados pelo autor no jornal A Gazeta, e neles é possível verificar que a intervenção do Estado nas questões do futebol aconteceu com o apoio de vozes, como o próprio Thomaz Mazzoni. Inclusive, frases, expressões e palavras presentes nos discursos dos dirigentes do Estado Novo, estão também presentes nas crônicas de Mazzoni. ${ }^{7}$ Ele não se conformava com o que denominava "desorganização do futebol brasileiro" (desorganização que, segundo o cronista, também marcava a sociedade brasileira). Acu-

5 Para o historiador Nicolau Sevcenko é fundamental destacar as relações entre a expansão dos espaços urbanos e a experiência do futebol. Este esporte pode ser considerado como uma prática que permite uma adaptação ao espaço industrial, marcado pelo tempo da fábrica. (SEVCENKO, Nicolau. Futebol, metrópoles e desatinos. Revista USP. São Paulo, n. 22, 1994).

6 Thomaz Mazzoni foi, durante muito anos, o mais importante cronista esportivo de São Paulo. Sua obra mais conhecida é História do Futebol no Brasil - 1894-1950, São Paulo: Leia, 1950, na qual o autor não se mostra preocupado em realizar grandes análises, mas em apresentar o máximo de informações possíveis sobre o futebol.

7 Fala-se em disciplina a todo custo e como objetivo fundamental; não se aceita o questionamento das decisões dos árbitros de futebol, afirmando-se que uns mandam e outros obedecem, e assim por diante. 
sava dirigentes, torcedores, jogadores, imprensa, além de outros setores ligados ao futebol, de praticarem o "clubismo", no qual cada personagem defendia seus próprios interesses, independentemente do que poderia acontecer para o desenvolvimento do futebol brasileiro. ${ }^{8}$ Para Mazzoni havia apenas uma saída: a intervenção e a autoridade do Estado, destruindo o "clubismo" e estabelecendo a ordem e a disciplina para o bem do futebol do Brasil e, conseqüentemente, para o bem da nação. ${ }^{9}$

Contemporâneo de Thomaz Mazzoni, o cronista carioca Mário Filho lançou duas obras importantes: Copa Rio Branco, 1932 - publicada em 1943, com prefácio de José Lins do Rego; e O Negro no Futebol Brasileiro - de 1947, prefaciada por Gilberto Freyre. No primeiro trabalho, tinha-se a preocupação em recuperar a história de um desacreditado selecionado brasileiro de futebol numa disputa - a Copa Rio Branco - com o selecionado uruguaio. Buscava-se mostrar o heroísmo dos brasileiros, que a despeito dos que acreditavam em uma vergonhosa participação do futebol brasileiro contra os campeões olímpicos e da I Copa do Mundo, voltam ao Brasil ostentando a conquista do referido torneio.

Porém, a grande obra de Mário Filho foi O Negro no Futebol Brasileiro, no qual busca construir uma explicação mais geral sobre o significado do futebol no Brasil e, ao mesmo tempo, tenta compreender por quê esse esporte, entre nós, havia adquirido uma forma tão especial, que passou a produzir os melhores jogadores do mundo. Porém, a tese central do livro é mostrar como o futebol teve a capacidade de gerar um processo de democratização racial no país. Através deste esporte, segundo Mário Filho, os negros puderam ocupar espaços dignos dentro da sociedade brasileira. Da mesma forma, o futebol brasileiro só havia atingido um alto nível de competência graças ao negro. Essa obra tornou-se clássica, a ponto de continuar sendo a matriz da maioria das análises acerca do futebol.

Thomaz Mazzoni e Mário Filho foram os cronistas esportivos que mais estiveram atentos - nos anos 1930 e 1940 - aos assuntos do futebol. Souberam perceber que não era possível pensar futebol desvinculando-o de questões mais gerais do país e do mundo. Nesse sentido, olhar para o futebol dessa época, passa, necessariamente, por esses dois cronistas esportivos.

8 De certa forma é a mesma crítica que Vargas fazia ao regionalismo, que não deixava que os verdadeiros interesses do país emergissem.

9 Thomaz Mazzoni deixava claro que só a intervenção do Estado, oficializando a prática do futebol - já profissional - é que teria poder na destruição de todos os males que perpassavam os esportes. Nesse sentido, não é difícil compreender o porquê de seu apoio ao Estado Novo. 
De certa maneira, podemos considerar que a luta desses cronistas esportivos - principalmente no caso de Thomaz Mazzoni, surtiu efeito. A partir de 1941, com a criação do Conselho Nacional de Desportos (CND), tivemos uma ampla legislação específica para todas as atividades esportivas, com os legisladores atentando para uma infinidade de detalhes, que deixavam claros seus intuitos centralizadores e disciplinadores. De modo explícito, o Estado apresentou-se preocupado em "tomar conta" dos esportes, assim como pretendeu controlar todas as atividades físicas, principalmente no espaço escolar. E o mais importante, como já afirmamos: essa ação estatal veio atender reclamos de parcelas da sociedade.

Consideramos que a prática esportiva e a sua disciplinarização não poderiam ser tratadas isoladamente, pois outros elementos apresentam-se como as questões do corpo e da educação. Por outro lado, não poderia se perder de vista que o Estado Novo faz parte do processo da chamada "Revolução de 30", na qual novas camadas assumem o poder e passam a reestruturar o Estado, com novas preocupações e interesses. Portanto, nesse período, a educação passou a ser vista de forma diferente, tornando-se um espaço estratégico na consolidação do novo Estado, com a presença desses novos personagens. Paralelamente a essa questão, ocorreu a preocupação dos novos setores hegemônicos em construir uma idéia de Nação e Povo. Nessa construção, o futebol adquiriu uma grande importância.

Ao mesmo tempo, é preciso abordar o futebol com a preocupação em compreender a sociedade brasileira, principalmente a partir da organização dos seus espaços urbanos. Ao analisar os caminhos percorridos pelo futebol em São Paulo e no Brasil, procuramos perceber como idéias sobre a cidade foram sendo construídas.

A partir dessas preocupações, procuramos compreender a experiência do futebol nos anos 1930 e 1940, a partir de dois eventos que sintetizam a idéia deste esporte-espetáculo enquanto um construtor da idéia de nação. Trata-se do Estádio do Pacaembu, inaugurado em 1940. Partimos da análise das primeiras idéias de se construir um estádio em São Paulo, que fosse compatível com a popularidade do futebol nos anos 1930 e também compatível com as concepções correntes nessa época acerca do corpo e do esporte, enquanto meio de "melhoramento da raça". Dessa questão, buscamos compreender o significado dessa construção enquanto um monumento de São Paulo para o Brasil. Outro evento, também colocado como sintetizador de uma experiência do futebol num momento especial de afirmação da construção da idéia de nação a partir do futebol: a participação brasileira na Copa de 1938, disputada na França. Traba- 
lhamos com o relacionamento entre o futebol e a construção da identidade nacional no Brasil, a partir dos anos 1930. Analisamos como esse esporte foi sendo articulado com a sociedade brasileira, a ponto de fazer daquela competição esportiva um momento de destaque na construção da identidade nacional.

Daí a importância da análise de um momento especial da história do futebol em São Paulo e no Brasil: os anos 1930 e 1940. Neste período, esse esporte passou por uma das suas muitas rupturas. O processo de profissionalização dos jogadores de futebol, associado à manutenção de uma estrutura amadora entre os dirigentes esportivos, juntou-se a uma preocupação estatal em ter cada uma das práticas esportivas em suas mãos. Coube ao Estado, pressionado por parcelas da sociedade, buscar saídas para a organização dos esportes nacionais, tratando de dar-lhes um novo significado. $O$ esporte a serviço da nação, título de uma obra do cronista esportivo Thomaz Mazzoni, não poderia ser mais representativo do que se desejava dos esportes, especialmente do futebol, por sua forte aceitação entre a maioria dos brasileiros.

Assim, o autoritarismo presente no Brasil, consubstanciado enquanto experiência de poder com o Estado Novo, não poderia se manter alheio ao fenômeno social que movimentava milhões de brasileiros e atitudes oficiais concretas, apontando para uma ligação mais efetiva com o futebol. Exemplo maior pode ser encontrado no apoio que o Estado vai proporcionar à delegação de futebol presente à Copa de 1938, realizada na França. Essa competição deixava de ser um momento de improviso, de divergências entre dirigentes regionais, para tornar-se um elemento crucial na construção ilusória de uma unidade nacional. Até então, nunca se havia visto tamanho empenho por parte do poder público em torno de uma competição esportiva. Esse evento mostrou o futebol adquirindo um outro significado dentro da sociedade brasileira.

Da mesma maneira, é com esse referencial que precisamos compreender a construção do Estádio do Pacaembu como produto de um contexto de reformulação urbana, marcado pelo seu espírito de servir ao desenvolvimento de uma ordem urbana-industrial, buscando beneficiar a acumulação do capital. Para o prefeito Prestes Maia, articulador dessas transformações urbanísticas, a construção do Estádio do Pacaembu foi a grande obra. Muito mais do que um espaço para a prática esportiva, essa construção cumpriu a função de tornar-se um monumento, capaz de sintetizar uma época.

Nessa mesma época, os trabalhadores da bola - os jogadores de futebol - também foram capazes de compreender que precisavam fazer com que suas atividades fossem reconhecidas efetivamente como de trabalhadores, mesmo com um caráter muito especial. Não poderiam mais ficar ao sabor de 
dirigentes exploradores, de uma imprensa sensacionalista e de uma torcida por demais cordial. Em momentos pontuais, alguns jogadores permitiram-se fazer opções profissionais, abandonando mitos, como o do amor à camisa. ${ }^{10}$ Nesse sentido, dentro de limites estruturais claros, buscaram contratos melhores, relações de trabalho menos exploradoras. Em muitos casos, tinham consciência da importância de aproveitar o auge da carreira. Na Copa de 1938, por exemplo, os jogadores sabiam o quanto significava para os brasileiros uma vitória em terras européias. Em função disso, mesmo num momento de extremo nacionalismo, voltaram-se aos dirigentes exigindo ganhos compatíveis com as responsabilidades atribuídas. Para esses atletas, se o futebol era profissional e eles viviam dessa atividade, era preciso que fossem remunerados a contento.

Assim, a conjugação de inúmeros eventos, com destaque à participação do selecionado brasileiro de futebol na Copa da França e à construção do Estádio do Pacaembu, o futebol tornou-se um forjador da unidade nacional. As características desse fenômeno social - que há muito havia ultrapassado a condição de uma mera atividade esportiva - foram decisivas para que o jogo da bola fosse um dos pólos utilizados para a construção da idéia de nação. E como se verá, o papel da imprensa - dos jornais e do rádio - foi muito importante. Daí a derrota na Copa de 1938 ter sido a derrota da nação, esta sim sendo prejudicada e não uma simples equipe de futebol. Os laços entre futebol e nação eram estreitados, tornando-se presentes até hoje.

\section{Copa de 1938: o futebol construindo a nação}

A participação brasileira na Copa de 1938 foi um momento especial dentro da história do futebol no país. Se este esporte experimentava um momento de transição entre a prática semi-amadora e a profissional, o processo que levou a ida dos brasileiros às terras européias produziu uma série de transformações dentro do futebol, principalmente no que se refere às suas relações

10 Porém, parte da imprensa esportiva continuava a destratar os jogadores profissionais, tratandoos como mercenários, isto quando não eram considerados "traidores da pátria". Note-se esta pequena entrevista feita com Feitiço, um importante jogador da época de transição para o futebol profissional: "(...) - Vou saltar no Rio e embarcarei hoje mesmo para São Paulo, onde permanecerei durante cinco dias em companhia de minha família. Espero estar no Rio dentro de uma semana no máximo. E conclui: - Ainda não sei qual será o meu clube no Rio de Janeiro. Jogarei para aquele que me der maior vantagem." (DECLARAÇÕES de Feitiço. O Estado de São Paulo, 12 abr. 1936, p. 14. 
com a sociedade. Sem dúvida, a Copa de 1938, realizada na França, significou uma nova etapa para o futebol no Brasil. Se este já era o esporte mais popular no Brasil, com essa Copa de 1938, esta condição atingiu níveis ainda mais altos. Pela primeira vez, o poder público (em todos os níveis) assumiu a condição de apoiador da delegação de futebol. Os destinos do selecionado já não cabiam apenas aos setores diretamente ligados ao esporte bretão, mas cada brasileiro sentiu-se responsável pelo desempenho de toda a equipe. Era como se a nação Brasil estivesse para ser testada em terras européias.

A apesar de não ser possível detectar um projeto claro das várias esferas do poder público no sentido de utilizar o futebol enquanto um legitimador da ordem política vigente, torna-se perceptível que o futebol desse período era considerado como colaborador, no sentido de reforçar a idéia da construção de uma identidade nacional. Verifica-se que setores da sociedade buscavam no futebol um fator de coesão nacional. Deve-se ter em conta que várias características deste esporte facilitam essa associação entre a sua prática e a idéia de nação. Ainda é comum o fato das cores de nações estarem estampadas nas camisas das seleções nacionais. ${ }^{11}$

Neste sentido, Marcos Alves de Souza discute a construção da imagem da nação brasileira pelo futebol, a partir dos referenciais gênero e raça e tendo como referência teórica Benedict Anderson, que define nação enquanto uma comunidade imaginada e mostra como também as torcidas de futebol podem ser consideradas comunidades imaginadas. ${ }^{12}$ Também em E. J. HOBSBAWM, a relação entre esporte e nação é analisada, só que dentro do contexto do Entre-Guerras. ${ }^{13}$ Ou seja, nesse período, para o historiador inglês, o esporte - com destaque para o futebol - constituía-se em peça fundamental para alimentar sentimentos nacionalistas.

Por outro lado, a aproximação que o poder político faz em direção ao futebol no Brasil, não foi exclusiva de um período, nem se deu de forma homogênea. Essa aproximação ocorreu quase na mesma medida em que o futebol

11 Assim, vale lembrar a definição de Nelson Rodrigues para a seleção brasileira, nos anos 50: "a pátria de chuteiras". Para Marcos Alves de Souza: "(...) o fato dela estar usando chuteiras significa que está pronta para jogar futebol, o que quer dizer que a nação simboliza e representa o conjunto de cidadãos homens do Brasil que comungam imaginariamente de uma unidade em torno de sua auto-afirmação da própria potência, e da defesa de sua 'frágil e indefesa' nação, representada como uma mãe." (SOUZA, Marcos Alves de. Gênero e Raça: a nação construída pelo futebol brasileiro. Cadernos Pagu, n. 6 e 7, Campinas, p. 150, 1996).

12 Ibid., p. 112.

13 "Entre as duas guerras, o esporte como um espetáculo de massas foi transformado numa sucessão infindável de contendas, onde se digladiavam pessoas e times simbolizando Estados-nações, o que hoje faz parte da vida global. (...)" (HOBSBAWM, E. J. Nações e nacionalismo desde 1870. Rio de Janeiro: Paz e Terra, 1990, p. 170). 
passou a se tornar mais popular. Assim, a ação estatal, até os anos 1930, resumiase em apoiar a prática futebolística, mas sem um maior empenho ou qualquer sistemática; efetivamente, o dinheiro público que chegava aos esportes ainda não era significativo, uma vez que continuavam sendo atividades de caráter essencialmente privado. ${ }^{14}$

Porém, independente das preocupações do poder público com os problemas do esporte, o que continuava a chamar a atenção dos torcedores era o futebol vivenciado e não discussões de gabinetes fechados, que mal os envolviam. E o que de fato interessava a esses torcedores, dentro do futebol, eram as competições, acopladas às conquistas. Por isso, de fins de 1936 a fevereiro do ano seguinte, os torcedores centraram suas atenções num momento especial: o selecionado de futebol voltava a participar do Campeonato Sul-Americano de Futebol, que não disputava desde $1925 .{ }^{15}$ Os torcedores brasileiros poderiam acompanhar as partidas através da transmissão radiofônica. ${ }^{16}$

O processo de profissionalização do futebol ainda não se mostrava consolidado no início da década de 1930 e as dificuldades provenientes da profissionalização continuavam presentes. Como aguçaram as rivalidades entre os amadoristas e os profissionalistas, ambos brigavam para controlar a direção dos esportes. Muitos clubes tiveram seus times enfraquecidos em função dos inúmeros jogadores perdidos para outros clubes, inclusive do exterior. Mas com a oficialização, concretizada em 1933, até fins de 1936, apesar das inúmeras dificuldades, o futebol brasileiro voltava a empolgar e a multidão de torcedores estava de volta aos estádios esportivos.

Mesmo continuando as discussões entre os defensores do profissionalismo e os do amadorismo, foi formada uma seleção relativamente forte para a disputa desse torneio sul-americano de 1936-7. Sobre a participação do futebol brasileiro nesse torneio, afirma Fontenele que:

...Essa foi a melhor campanha do Brasil no Prata pelo tradicional torneio continental. Apesar de ainda existir crise interna (cisão no Rio com duas entidades), e a CDB não poder contar com o concurso de jogadores da Liga Carioca de futebol, especialmente da dupla

14 Para A Gazeta, além de o poder público não ajudar os esportes, ainda atrapalhava, com a excessiva cobrança de impostos; A Gazeta defendia a isenção de impostos para as atividades esportivas. (MAZZONI, Thomaz. Cifras oficias... A Gazeta, 19 maio 1937, p. 11.

15 FONTENELE, Airton Silveira. O Brasil na Copa América, [s.1., s.c.p.], 1989, p. 38.

16 Como pode ser encontrado num anúncio da rádio Cruzeiro do Sul e da rádio Sociedade Record. O Estado de S. Paulo, 31 jan. 1937, p. 5. 
Fla-Flu, o técnico Adhemar Pimenta levou para a capital portenha uma forte equipe... ${ }^{17}$

O embate final, para a conquista do título, colocou os brasileiros frente aos argentinos, os donos da casa. A melhor campanha do time brasileiro permitia que o título seria conseguido com um simples empate nessa partida. Veio a derrota por 1 a 0 , em um jogo cheio de confusões, com uma briga generalizada entre todos os atletas.

Na recepção, ocorrida no porto do Rio de Janeiro, o espírito do heroísmo nacional passou a ser alimentado: já não eram jogadores e sim soldados que voltavam - em parte vitoriosos - da guerra. Foram recebidos com uma grande festa de caráter cívico, e os jornais louvaram menos o resultado final e mais a disposição de luta dos atletas nacionais:

...A esposa de Nariz desfraldou a bandeira do Brasil e nesse momento a multidão prorrompeu em aplausos ensurdecedores:

- Viva o Brasil! (...)

Nesse momento era incalculável a multidão que se aglomerava na Praça Mauá. (...) Assim, Adhemar desceu, fê-lo nos braços de torcedores que o carregavam em triunfo. Também Roberto, Tim e Afonsinho apareceram nos braços da multidão.(...)

Em seguida, o sr. Luis Aranha cedeu a palavra ao chefe da delegação brasileira, sr. Castello Branco, que agradecendo as carinhosas homenagens que se prestavam aos jogadores, ressalta que o feliz êxito obtido pela representação se devia à disciplina, patriotismo e perfeita compreensão esportiva de todos os seus componentes.(...) Após o discurso de Roullien foi praticamente encerrada a solenidade na Esplanada do Castelo, tocando as bandas militares o Hino Nacional... ${ }^{18}$

A festa foi marcada pela forte presença simbólica da bandeira nacional, sendo o hino pátrio tocado diversas vezes e os discursos precedidos pela salva de 21 tiros. Essas festividades seriam um prenúncio do que viria no ano seguinte. Ao mesmo tempo, o empenho de alguns dirigentes do esporte nacional em levar o futebol do Brasil de volta aos campeonatos sul-americanos parecia ter sido um sucesso. A euforia dos que acompanharam as partidas da

17 FONTENELE, op. cit., p. 38.

18 Os futebolistas brasileiros tiveram entusiástica recepção no rio. O Estado de S. Paulo, 07 fev. 1937 , p. 10 . 
seleção pelo rádio, além da grandiosa manifestação dos torcedores na recepção dos defensores do futebol brasileiro em terras estrangeiras, mostrava o potencial mal-aproveitado do esporte mais popular do país.

Se a participação brasileira no torneio sul-americano repercutiu intensamente, nada poderia ser comparado ao que se viveria em 1938. Entre os efeitos mais claros, pode-se verificar que os vínculos da sociedade brasileira com o futebol aumentaram. A Copa do Mundo, disputada na França, avultou a paixão por esse esporte, assim como foi capaz de suscitar inúmeras questões acerca da própria concepção de nação. Uma leitura dos jornais da época passa a idéia de que não foi um evento qualquer e sim um momento da história do país que movimentou pessoas nas mais diversas regiões. Era como se os destinos do Brasil estivessem sendo decididos entre um chute e outro.

Ocorreu um sistemático envolvimento dos periódicos, objetivando aproximar os torcedores das questões organizacionais do futebol. Em São Paulo, essa tarefa foi aceita com muita naturalidade pelo jornal $A$ Gazeta, que produzia um suplemento esportivo semanal, A Gazeta Esportiva. Assim, no início de abril de 1938, quando a seleção brasileira de futebol já se preparava para disputar a Copa do Mundo na França, a Confederação Brasileira de Desportos (CBD) lançava a "Campanha do Selo", que imediatamente é apoiada pela Gazeta:

A Campanha do Selo, a tão bem inspirada iniciativa, teve um sucesso invulgar, ao se iniciar há dias, no Rio, está quase esgotada a emissão de 100 mil selos. Com essa campanha os afeiçoados podem se interessar diretamente pela viagem da nossa seleção, pois adquirindo um selo o "torcedor" faz sua fezinha de ir também à “Taça do Mundo”. É a sorte que designará o feliz afeiçoado que acompanhará a delegação(...)

Melhor iniciativa para interessar os nossos afeiçoados não poderia surgir. Os que adquirirem o "selo cebedense" não só auxiliarão patrioticamente o comparecimento do Brasil na III "Taça do Mundo" como se tornarão, igualmente, candidatos a um lugar na delegação por...500 réis. Assim, enquanto os "fans" gastarão uma quantia tão modesta, a CBD, para cada emissão, arrecadará 50 contos, uma quantia que muito contribuirá para a nossa seleção viajar com maior comodidade, para melhor se hospedar na França, etc. E tudo isso importa na melhor disposição dos nossos "azes" para lutar naquele importante torneio dentro de suas reais possibilidades. Sendo assim, maior será nossa "chance" de vitória. Quanto melhor conforto tiver o "XI" brasileiro, tanto melhor será a margem que teremos para impor nosso valor. 
Adquirir o "selo" não é, pois, somente a esperança própria de se ir à Europa assistir o Campeonato Mundial, como também um ato patriótico para melhor servir o nosso ideal comum de vermos o Brasil atingir o posto supremo no futebol internacional que seria a conquista da "Taça do Mundo"! 19

Thomaz Mazzoni deixa claro que joga a responsabilidade do sucesso, ou não, da seleção brasileira de futebol nas mãos dos torcedores; eram estes que deveriam estar financiando parte da viagem dos futebolistas, pois quanto mais conforto, quanto melhores fossem as acomodações e o transporte, maior seria a possibilidade dos jogadores brasileiros desempenharem suas habilidades da melhor maneira possível.

Porém, não caberia apenas aos torcedores ajudar na participação do selecionado nacional na Copa da França. A diretoria da CBD entendia que o apoio do poder público, assim como do empresariado, era fundamental e justo, já que não se tratava de uma disputa esportiva qualquer. Dessa forma, podemos encontrar nas páginas dos periódicos as justificativas para que o apoio material à delegação esportiva brasileira fosse o mais amplo possível.

Se os benefícios da ida do futebol brasileiro seriam do país como um todo, segundo a visão dos dirigentes da CBD, todo o país teria de contribuir para o sucesso do futebol brasileiro. Assim, ainda segundo o noticiário da Gazeta:

Anteontem, a entidade máxima nacional, dirigida pelo sr. Luiz Aranha, já deu início aos treinos da representação.

Dado o grande vulto de despesas para que a nossa seleção representativa tenha todo o conforto indispensável, a CBD houve por bem angariar entre os interventores federias nos Estados, no comércio especial, os muitos indispensáveis e, assim, já se dirigiu por ofício aos interventores nos seguintes Estados: Amazonas, Pará, Maranhão (...) aos diretores da Companhia Light, Instituto do Açúcar e do Álcool, Banco do Brasil (...)

Concorrerão também o alto comércio e as indústrias de São Paulo... ${ }^{20}$ 
Enfim, como a disputa da Taça do Mundo poderia colocar o nome do país em evidência, como também poderia redundar num grande fiasco, cabia à CBD organizar e dirigir as forças nacionais no sentido de fazer da Copa da França um momento especial para o país. E cabia ao povo brasileiro aceitar, de maneira disciplinada, essa direção e contribuir para o sucesso da delegação brasileira. ${ }^{21}$

Outros movimentos que envolviam a participação do futebol brasileiro na França colaboravam para demonstrar o quanto essa disputa foi adquirindo um caráter cada vez mais importante, como por exemplo, as preparações para a realização das transmissões radiofônicas das partidas do selecionado nacional. ${ }^{22}$

As autoridades brasileiras aproximaram-se do futebol nesse campeonato, pois a CBD já escolhera a filha do presidente, Alzira Vargas, para ser madrinha da seleção, e o embaixador do Brasil na França, Souza Dantas, revela o seu entusiasmo pelo futebol, proclamando-se o torcedor $\mathrm{n}^{\circ} 1$ do país. O embaixador, com o peso do seu cargo, representava mais um elo de ligação na construção de uma nação pronta para fazer do Brasil um vencedor, mesmo que fosse através do futebol. A imagem que se construía era a de uma nação que enfrentaria uma luta.

Enfim, a aproximação do início da Copa do Mundo de 1938 fazia com que cada setor da sociedade brasileira se envolvesse cada vez mais com o futebol, como se toda a nação estivesse naquele momento representada. A nação, unida, mostrava-se atenta para enfrentar os inimigos que viessem pela frente; a unidade nacional foi trabalhada de tal maneira no imaginário popular que, mesmo aqueles que possuíam pouco ou nenhum interesse pelo futebol, não conseguiram se manter à parte.

Domingo, quinto dia do mês de junho de 1938, finalmente a seleção brasileira de futebol entra em campo na busca de uma vitória, que permitiria que o time avançasse rumo ao título. Alguns anos mais tarde, Mazzoni descrevia dessa forma essa primeira partida:

21 " (...)A relação inicial das adesões é a seguinte: Banco do Brasil, 20\$000; Cia. Souza Cruz, 10\$000; Banco do Comércio e Indústria, 10\$000;(...) Cia. Financial, 5\$000.(...)" Tudo pela boa representação e propaganda do Brasil à "Taça do Mundo"!, (A Gazeta, 30 mar. 1938, p. 8).

22 Em material publicitário da própria A Gazeta, era anunciada a presença do rádio nos jogos da Copa do Mundo: " (...) O Rádio Clube do Brasil será o único que fará as irradiações do Campeonato Mundial. O som da Rádio Clube do Brasil, porém, será retransmitida pela rede nacional de emissoras. Deve-se assinalar outro aspecto auspicioso: todo o Brasil ouvirá a irradiação. (...) a irradiação será retransmitida para todos os Estados da Federação pela Rede Nacional. (...)" (A Irradiação dos Jogos do Brasil na Taça do Mundo. A Gazeta, 07 abr. 1938, p. 8). 
Chegou o dia da nossa $1^{\mathrm{a}}$ partida e minutos após iniciado o prélio, contra a Polônia, o público teve a certeza de que os brasileiros venceriam por 7 ou 8 gols (...) Superioridade absoluta. Mas, nosso quadro, sempre com a velha mania das brincadeiras facilitou tanto que o prélio terminou empatado. Incrível, estivemos a pique de sofrer um grande castigo. (...)Vencemos na prorrogação por 6 a 5 e a lição ficou... ${ }^{23}$

Segundo Mazzoni, o time começou a desrespeitar os adversários, utilizando-se de jogadas de muito efeito plástico, mas sem qualquer objetividade, que seria a marcação de mais gols e selando o resultado a favor dos brasileiros. $\mathrm{O}$ adversário foi-se sentindo humilhado e reagiu, empatando o jogo em 4 a 4 , levando a partida para uma prorrogação. No final, vitória do time do Brasil, por 6 a 5 .

...Em senso técnico, a superioridade do Brasil foi absoluta: cada jogador brasileiro deu verdadeira lição de estilo; mas o mal foi justamente cuidar-se mais da técnica, em prejuízo da mobilidade e impulso do conjunto, que lhe faltam quando mais era necessário... ${ }^{24}$

Para Thomaz Mazzoni, faltou algo fundamental: a preocupação com o jogo coletivo, em que a atuação de cada atleta deve estar a serviço do coletivo, do grupo. De certa forma, o cronista da Gazeta construía uma analogia com os debates que se faziam no Brasil, principalmente após o golpe de 10 de novembro de 1937. Esse era o discurso que vinha do regime ditatorial: os esforços individuais devem estar a serviço da coletividade, da nação, a partir dos interesses nacionais. Dessa forma, não poderia haver espaço para os particularismos regionais, pois não importava o sucesso de uma região ou de uma atividade econômica, mas do progresso homogêneo do país, expressão recorrente na época.

A reação dos torcedores, por todos os cantos do país, em função da dramática vitória da seleção foi significativa:

Torcendo pela vitória dos brasileiros - Matou-o a emoção!

Campos, 6 (do correspondente) - Toda a cidade recebeu 
consternada, após a notícia alvissareira da vitória brilhante dos brasileiros sobre os poloneses em disputa do Campeonato Mundial de Futebol, a notícia de que, fulminado pela emoção intensa, falecera o chefe da estação postal-telegráfica, sr. Dario Balesdent. (...) - Sexto gol dos brasileiros!

Balesdent ouve e rompe em vivas ao Brasil. Silencia repentinamente e sente obscurecer-lhes a visão. Chama a esposa, que ao chegar apressadamente vê o marido já estendido, agonizando. Quando chegou o médico, o sr. Dario Balesdent era cadáver.

Deixa o extinto viúva a sra. Maria Balesdent e órfão o sr. Enéas Balesdent, médico. Tinha 49 anos de idade e chefiava os serviços postais-telegráficos havia muitos anos. ${ }^{25}$

Já um periódico mineiro organizou um "bolo" em relação a essa partida contra a Polônia e um estudante acertou o resultado, ganhando 1:350\$000. ${ }^{26}$

A morte do torcedor na cidade de Campos, no antigo estado da Guanabara, como o estudante que ganhou o bolão em Minas Gerais, constituíam uma pequena amostra da forma como os brasileiros se comportaram diante de jogo tão emocionante. A imprensa fazia questão de mostrar que as manifestações vinham de todos os rincões do país, dando a entender que se tratava de um acontecimento de repercussão nacional; era o brasileiro envolvido com os destinos do futebol nacional.

Porém, o poder da vitória do quadro brasileiro produzia efeitos muito mais complexos, que mereciam uma atenção maior dos jornalistas esportivos. Nesse sentido, destacava-se um comentário publicado na Gazeta sobre o comportamento dos torcedores na cidade de São Paulo após a peleja contra o time polonês, guardado sob um título instigante: "Estrangeiros, mas brasileiros":

Mil, dez mil, duzentos mil ou número maior de pessoas, talvez a população inteira de São Paulo manifestou domingo a sua grande alegria pelo triunfo dos brasileiros na primeira partida da "Taça do Mundo". (...)

Impossível que não vencêssemos tal jogo, daí o desespero indisfarçável que se apoderou de todos, a atmosfera pesada que envolveu São Paulo como teria envolvido o país inteiro. ${ }^{27}$

25 Torcendo pela vitória dos brasileiros - matou-o a emoção! Correio da Manhã, 07 jun. 1938, p. 20.

$26 \mathrm{O}$ valor ganho nesse bolão eqüivalia a cinco salários médios de um operário. Correio da Manhã, 09 jun. 1938, p. 7.

27 Estrangeiros, mas brasileiros. A Gazeta, 07 jun. 1938, p. 10. 
Mas, para a Gazeta, não fora apenas uma vitória dos brasileiros:

\begin{abstract}
...Milhões de brasileiros sofreram, mas com eles sofreram também milhares de estrangeiros.

Italianos, portugueses, húngaros, espanhóis, e filhos de outros países se associaram aos nossos sentimentos patrióticos e nisso residiu o nosso maior conforto. (...)

Domingo, em São Paulo, todos foram brasileiros e bons brasileiros, e uma prova temo-la nos 'botecos' de portugueses, nas 'cantinas' de italianos, nas residências dos húngaros e em outros lugares habitados por estrangeiros, onde enormes cartazes foram colocados às portas, com o resultado do encontro, e foguetes espoucaram em regozijo pelo triunfo.

Os sofrimentos e as alegrias foram gerais, São Paulo, a 'terra estrangeira' foi mais brasileira do que nunca... ${ }^{28}$
\end{abstract}

O futebol conseguia unir povos diferentes, todos em torno da nação brasileira. Assim, se de um lado, brasileiro era o que torcia pelo selecionado nacional - independente do lugar de nascimento -, por outro, era também aquele que trabalhava para o progresso da nação. Além de construir a unidade nacional, o futebol do Brasil conseguia harmonizar povos. ${ }^{29}$

A Gazeta ainda resolveu organizar o envio de um telegrama coletivo para os representantes do Brasil na França; qualquer pessoa ou instituição poderia aderir a mais esta maneira de mostrar-se solidária com os que defendiam o nome da "pátria":

Delegação Brasileira Campeonato Mundial - Bordéus - Esplendor vosso primeiro triunfo arrebatou entusiasmos paulistas. Avante, dai-nos mais uma vez vitória, honra para vós, glória Brasil. Recebei através da GAZETA nossas saudações. GAZETA. ${ }^{30}$

Na partida contra a seleção da Checoslováquia, também, manifestações de caráter oficial, como a do ministro da Educação, Gustavo Capanema:

28 Id.

29 As notícias que vinham do Rio de Janeiro mostravam-se tão alvissareiras quanto as apresentadas pelo cronista esportivo da Gazeta, porém fazendo referência aos portugueses. (O Jogo Brasil-Polônia e a confraternização das colônias, A Gazeta, 08 jun. 1938, p. 1).

30 Encorajemos os nossos "azes" à vitória!, A Gazeta, 10 jun. 1938, p. 10. 
(...) Adhemar Pimenta, delegação esportiva do Brasil - Marselha A vitória de hoje tem um sentido: tudo pelo Brasil. Peço levar aos nossos invencíveis lutadores a minha palavra de entusiasmo e louvores - Gustavo Capanema, ministro da Educação. ${ }^{31}$

Esta seria uma das primeiras manifestações oficiais do governo federal acerca da participação até então vitoriosa dos futebolistas brasileiros; e com o reforço da idéia de que lutar dentro do campo era trazer glórias para o país.

As felicitações continuavam, desta feita pela filha de Vargas:

... Confiante na vitória do Campeonato, envio-lhes entusiásticos cumprimentos pela magnífica afirmação esportiva de hoje. ${ }^{32}$

Também a presidência da República manifestava:

(...) O Gabinete Civil e Militar do presidente Getúlio Vargas congratula-se com a brilhante vitória dos valorosos e esforçados jogadores patrícios - Luiz Vergara e general Francisco José Pinto. ${ }^{33}$

E como se tratava de um importante momento de afirmação da nacionalidade, também as empresas privadas sentiram-se envolvidas nesse processo. Nesse sentido, chama a atenção uma experiência vinda de Curitiba:

A fim de permitir que os seus empregados pudessem ouvir a irradiação da partida de futebol entre brasileiros e tchecos, os bancos, escritórios e várias casas comerciais encerraram o expediente pouco antes de ser iniciada aquela irradiação. ${ }^{34}$

Mas veio o jogo contra os italianos, apenas dois dias após a árdua e cansativa partida contra os tchecos. Os brasileiros continuavam colaborando, a partir das suas possibilidades, para que a equipe nacional novamente obtivesse êxito. Da mesma maneira que eram mandados telegramas de felicitações pelas vitórias, também eram remetidas mensagens animando-os para a partida

31 A palavra de entusiasmo do Ministro da Educação. Correio da Manhã, 15 jun. 1938, p. 1.

32 Da Srta. Alzira Vargas. Correio da Manhã, 15 jun. 1938, p. 1.

33 Da Presidência da República. Correio da Manhã, 15 jun. 1938, p. 1.

34 Id. 
seguinte. Só que nem tudo aconteceu como a maioria dos brasileiros desejava. Thomaz Mazzoni assim descreveu essa partida:

O quadro contrário [a Itália] fez uma grande partida, o juiz o resto...Com um penal contra, perdemos por 2 a 1 , mas foi o bastante para não chegarmos mais ao título! Não tivemos outro remédio senão ir nos consolar com o $3^{\circ}$ posto... Voltamos tristes e desesperados para Bordéus.

(...)

Todos queriam, porém o primeiro lugar. Por isso a grita, aqui no Brasil foi grande...

Acusações a Pimenta, censura a certos jogadores, o diabo...

A verdade, porém, é que o Brasil fez bonito. A má sorte não quis que o XI brasileiro fosse campeão, eis tudo.

O jogo contra a Itália...resultou na única derrota do Brasil. Muito se comentou.

Aquele dia fatídico quase causou uma...revolução no Brasil.

Todo mundo deixou de trabalhar [foi uma quinta-feira] o decorrer do jogo causou intenso nervosismo, indignação depois, devido ao penal, enfim, não foram poucos os incidentes... ${ }^{35}$

Mazzoni assistiu ao jogo no qual o selecionado do Brasil foi derrotado pelo placar de 2 a 1 . O lance mais polêmico da partida havia sido uma penalidade máxima marcada contra o time brasileiro, quando a equipe italiana já vencia por 1 a 0 . Segundo Mazzoni, esse foi o ponto mais polêmico de toda Copa, já que aquela penalidade, segundo as regras do futebol, não poderia ser marcada, pois quando o jogador italiano Piola foi atingido pelo brasileiro Domingos da Guia, a bola estava fora de campo.

E se a euforia popular havia tomado conta das cidades, a derrota trouxe momentos de apreensão entre os torcedores. Assim, num momento tão apaixonante como em um jogo decisivo de Copa do Mundo, a relação dos torcedores brasileiros não poderia ser diferente. A seguinte notícia, vinda de Fortaleza, logo após a partida contra a equipe italiana, pode auxiliar no dimensionamento dessa questão:

Em conseqüência do grave nervosismo popular verificaram-se ontem à noite numerosos incidentes pessoais. 
Merece ser destacado o caso da jovem Maria de Lourdes, de 22 anos de idade, a qual torcia apaixonadamente e, ao saber da derrota do team brasileiro, tentou suicidar-se ingerindo forte dose de veneno. Maria de Lourdes encontra-se em estado gravíssimo. ${ }^{36}$

Essa jovem havia-se envolvido de maneira tão forte com os destinos do futebol brasileiro, confundindo-os com os destinos do país, que a derrota era mais do que insuportável. Essas reações se repetiram por todo o país.

Ao mesmo tempo, passou-se a debater o porquê da não conquista da cobiçada Copa do Mundo, a partir de uma questão mais ampla: porque o time do Brasil, formado pelos considerados como os melhores jogadores do torneio, além de deter um estilo futebolístico superior aos europeus, não ganhou? O suposto prejuízo causado pelo árbitro não parecia uma explicação suficiente.

Para muitos analistas da participação brasileira na Copa da França, a equipe nacional foi prejudicada em muitos momentos, o que demonstrava a má vontade dos dirigentes do futebol internacional para com os brasileiros. Assim, outra questão se apresentava: por que a má vontade dos europeus com um time de outro continente? Para um cronista esportivo da Gazeta, o problema poderia ser resumido da seguinte maneira: o regionalismo dos europeus não permitiu que o Brasil e o seu futebol fossem tratados com um mínimo de igualdade. Esse tratamento desigual, sofrido pelo time brasileiro, poderia ser atribuído a uma situação de isolamento do selecionado nacional, pois fora o único representante da América do Sul, já que as outras forças futebolísticas deste continente preferiram não disputar a Copa da França, que foi o caso da Argentina e do Uruguai. ${ }^{37}$

Já para Mazzoni, o Brasil - a partir do futebol - havia sido vítima de má fé por ser uma nação sem qualquer expressão no quadro mundial; ou seja, não era uma nação que mereceria maior respeito dos organizadores da Copa de $38 \mathrm{e}$ dos dirigentes da FIFA - assim, enfatiza a questão das arbitragens. Mas o futebol brasileiro, ainda segundo Mazzoni, também não soube articular-se politicamente dentro dos bastidores da Federação Internacional do Futebol Association (FIFA). Mazzoni dizia, mesmo sem explicitar, que a poderosa Itália fascista soubera fazer o trabalho de "bastidor". Outra questão foi levantada, agora em relação aos jogadores: estes não foram capazes de compreender a importância daquele momento para o futebol do Brasil e para a própria nação.

36 Tentou suicidar-se ao saber da derrota dos brasileiros, Correio da Manhã, 18 jun. 1938, p. 14. 37 EME-EME, A FIFA e os sul-americanos, A Gazeta, 18 jun. 1938, p. 9. 
Surgiu ainda no Brasil, e aguçou-se na França, uma forte rivalidade entre os jogadores do time titular e os do time reserva. Daí a observação do cronista de A Gazeta:

Quando os homens do esporte, no Brasil, conseguirem dar outra mentalidade aos nossos jogadores, então poderemos dar às nossas delegações chefes que ajam de outra maneira, sem dúvida, como requerem os sãos princípios da disciplina esportiva e cívica, especialmente em se tratando de uma representação nacional a uma competição internacional, em que acima de tudo deve pairar o nome da Pátria!

(...)

Em suma, a direção da embaixada nada deixou a desejar, podendose dizer que poucas vezes uma delegação esportiva brasileira seguiu para o estrangeiro melhor dirigida e orientada. ${ }^{38}$

Em outras palavras, se a direção do futebol brasileiro na Europa agiu sempre corretamente, o mesmo não poderia ser dito dos atletas que representavam o Brasil na Copa do Mundo. Estes continuavam pouco conscientes do que significava o futebol naquele momento da história do país.

Para o cronista esportivo d' O Estado de S. Paulo, PANTOJA, J. R., a arbitragem prejudicou o selecionado, porém, esse não era ponto fundamental para se explicar a derrota do futebol na França. Aliás, para ele:

...esta história de se atribuir apenas aos árbitros europeus o insucesso do nosso 'association' é recurso muito pouco convincente e de uma deselegância bastante reprovável e que evidencia ainda mais a fragilidade dos conhecimentos técnicos futebolísticos que intervieram na organização da representação cebedense.$^{39}$

Por outro lado, a participação popular continuava no momento de receber os "heróis nacionais", que levaram o nome do Brasil para os lugares mais altos, os que propiciaram momentos de muita alegria e emoção a cada brasileiro. Esses jogadores foram recebidos como mereciam e como a maior parte da imprensa gostaria que fossem recebidos: como os novos heróis da nação. Os

38 MAZZONI, Thomaz. O Brasil na Taça do Mundo, p. 114.

39 PANTOJA, J. R. Outra falha. O Estado de São Paulo, 03 jul. 1938, p. 13. 
detalhes da recepção do selecionado de futebol eram apresentados pelos periódicos:"

\begin{abstract}
...Cerca das 15 horas e meia o "Almanzora" em que viajaram os esportistas brasileiros começou a manobrar para a atracação. Na praça Mauá via-se a grande multidão que entusiasticamente aclamava os jogadores. A polícia a posto estabeleceu cordões de isolamento, a fim de facilitar o desembarque. (...)

A bordo o centroavante da seleção brasileira, interrogado por que não desembarcava juntamente com seus companheiros disse: 'Em Pernambuco e na Bahia também havia cordões de isolamento e quase fui vitimado pela multidão. Na cidade de Salvador levaramse da Cidade baixa para a Cidade Alta, a minha via crucis foi tal que até perdi um sapato... ${ }^{40}$
\end{abstract}

A participação brasileira na Copa de 38 , em função de todo clima que se criou, mostrou que o futebol já havia adquirido um papel fundamental: articulador da unidade nacional. Essa influência do futebol foi muito bem utilizada pelo poder público, bastando que se olhe todo o empenho demonstrado pelas mais diferentes autoridades brasileiras. Porém, também coube à imprensa uma função vital; os periódicos vivenciaram plenamente o clima de Copa do Mundo. Mais do que meio de informação ou análise, os jornais animaram o torcedor, ou iludiram-no com o otimismo exagerado de alguns cronistas esportivos. O rádio, como grande novidade numa transmissão direta da Europa, também se mostrou fundamental.

Esse momento de Copa contribuiu, de forma decisiva, para fazer com que o futebol aumentasse os seus vínculos com a sociedade brasileira. Essa competição, além de aumentar a paixão pelo futebol, foi capaz de suscitar inúmeras questões acerca da própria concepção de nação. Pessoas das mais diferentes regiões do país mostraram-se atentas e solidárias para com o destino do futebol do Brasil.

Simbolicamente, reforçou-se a idéia de que não era uma mera disputa esportiva, mas uma provação com o intuito de mostrar a força do Brasil, do seu povo, a partir do futebol. De diversas maneiras, cada brasileiro foi responsabilizado pelo desempenho dos atletas do Brasil.

40 A recepção dos futebolistas brasileiros no Rio. O Estado de São Paulo, 12 jun. 1938, p. 5. 


\section{O Estádio do Pacaembu: “monumento paulista” ao futebol}

As notícias acerca do futebol desde meados dos anos 10 deixavam uma coisa cristalina: a população de São Paulo e a paixão pelo futebol haviam crescido mais do que a capacidade dos estádios paulistanos em receber os torcedores. A cidade, que acolhia novas indústrias e se abria para as mais diversas atividades econômicas, era também a cidade dos imigrantes, dos bairros operários, das partidas jogadas na várzea e do futebol disputado nos campos. As grandes partidas do início dos anos 1920 - Corinthians Paulista contra o Paulistano e contra o Palestra Itália e, este contra o Paulistano - que revelavam as divisões sociais presentes em São Paulo, tornaram os campos de futebol pequenos. As multidões que invadiam esses estádios a cada partida decisiva mostravam como o gosto pelo esporte bretão havia aumentado e revelavam a necessidade de se pensar na construção de um novo estádio para a cidade.

Nas seções esportivas dos periódicos, os relatos sobre uma partida importante davam espaço para outros acontecimentos que não apenas o jogo em si. Se até o início da década de 10, o jornalista admirava-se com a quantidade de torcedores - que ele preferia chamar de assistentes -, destacando o comportamento em geral e as vestimentas das representantes do "belo e frágil sexo", com a chegada da década seguinte, essa situação modificara-se. Os torcedores tornaram-se parte essencial do espetáculo. Nicolau Sevcenko considera que o ano de 1919 marcou um momento especial do futebol em São Paulo. O campeonato desse ano na cidade empolgava os torcedores e verdadeiras multidões tomavam, a cada final de semana, os estádios da cidade, que, como nunca, mostravam-se pequenos, perigosos e desconfortáveis:

A assistência de ontem ao jogo Palestra X Paulistano no Parque Antártica bateu, cremos, o recorde das lutas esportivas em São Paulo. Cerca de 40 mil pessoas acorreram à grande praça de esportes do Palestra. (...) As arquibancadas e as gerais, como as cercas ao redor do campo, ficaram cheíssimas - é o termo. Nas árvores, mais do que na outra vez, no domingo anterior, instalaram-se numerosos espectadores, vergando-lhes os ramos ao peso da estranha carga. Na cobertura das arquibancadas, sobre as telhas de zinco escaldante, havia tanta gente, que os felizardos que estavam mais ou menos sentados ou em pé, ao abrigo do sol e da chuva, receavam que lhes caísse por cima aquele pedaço de céu velho... ${ }^{41}$

41 Palestra X Paulistano - a assistência, O Estado de São Paulo, 17 nov. 1919, p. 4. Apud: SEVCENKO, Nicolau. Orfeu Extático na Metrópole - São Paulo sociedade e cultura nos frementes anos 20. São Paulo: Companhia das Letras, 1992, p. 58-59. 
Apesar de necessário, o novo estádio só sairia do papel na década de 1930. Em 1936, na administração do prefeito Fábio Prado, a construção do estádio municipal teve início e só terminaria em 1940, já em outra administração. No lançamento da pedra fundamental, o caráter de monumento da obra começava a ser esboçado. Nessa cerimônia, Nicanor Miranda ${ }^{42}$ proferiu um discurso ressaltando que a construção do estádio municipal estava ligada diretamente ao crescimento de São Paulo:

Há seis lustros o nosso Município acusava uma população seis vezes menor que hoje e o seu perímetro era algumas vezes mais exíguo que o atual. (...)

Mas a cidade evoluiu. Os negócios tomaram vulto. A edificação intensificou-se. Começaram a surgir os arranha-céus. No centro, as construções se multiplicaram e os bairros próximos transformaram-se em núcleos comerciais ou residenciais.

A cidade cresceu. E as crianças, os adolescentes e os adultos foram condenados, pouco a pouco, a ficar sem áreas livres, sem espaços verdes, imprescindíveis para as suas atividades recreativas... ${ }^{43}$

Assim, a construção de um grande centro esportivo, o Estádio Municipal, permitiria incorporar os trabalhadores da cidade nas atividades físicas, devidamente "organizadas e dirigidas".

Dessa maneira, o Estádio Municipal do Pacaembu tornou-se um marco fundamental do futebol em São Paulo e no Brasil. A decisão pela sua construção deu-se num momento-chave de transformações urbanas, correlacionadas com uma nova postura frente às atividades físicas.

Nesse momento, as atividades físicas viviam um momento de extremo prestígio e a cidade mostrava-se a cada dia mais ligada à economia industrial. Após um início tímido, ainda em 1936, a construção do estádio sofre uma guinada com a vitória do regime autoritário em 1937, e a conseqüente posse de um novo prefeito - Francisco Prestes Maia. Este traz consigo uma nova concepção de intervenção no espaço urbano. ${ }^{44}$ Além de o estádio ter a sua construção acelerada, o projeto inicial foi modificado. Buscou-se, com o novo prefeito, a construção de um monumento.

42 Nicanor Miranda era o chefe da Divisão de Educação e Recreio do Departamento de Cultura da cidade de São Paulo.

43 Noticiário - Estádio Municipal - Lançamento da pedra fundamental. Revista do Arquivo Municipal, São Paulo, n. 29, nov. 1936, p. 207.

44 Sobre as transformações urbanas ocorridas em São Paulo no período do Estado Novo, ver: DIÊGOLI, Leila Regina. Estado Novo- Nova Arquitetura em São Paulo. São Paulo, 1996. Dissertação (Mestrado) - Programa de Estudos Pós-Graduados em História da Pontifícia Universidade Católica de São Paulo. 
Em abril de 1940, o Estádio Municipal do Pacaembu foi entregue à população de São Paulo em meio a muitos festejos, nos quais predominaram elementos simbólicos que sinalizavam a função cívica do estádio-monumento. Importava para São Paulo mostrar a sua força para o resto do país, da mesma forma que o Brasil mostraria esse poderio para os outros países sul-americanos. O poder público de São Paulo teve o cuidado de preparar minuciosamente a apresentação da sua grande obra. Num comunicado dirigido, entre outros setores, para a imprensa paulista, afirmava a prefeitura:

\begin{abstract}
...São Paulo deve, com efeito, engalanar-se afim de aparecer da maneira mais resplandecente durante o período de festejos inaugurais do seu majestoso Estádio Municipal

(...) Assim, poderá receber, de maneira brilhante, a imensa leva de forasteiros que, evidentemente, acorrerá para assistir ao invulgar certame. Será, sem dúvida alguma, um período excepcional para a vida do município. ${ }^{45}$
\end{abstract}

São Paulo, por ocasião da inauguração, deveria sintetizar, a partir de uma grande festa, os patamares de progresso que o país havia atingido com o regime autoritário que havia se instalado no poder com o golpe de 1937. Era preciso mostrar a capital paulista como símbolo e modelo do desenvolvimento econômico, muito ligado aos avanços na Educação Física. Isso caberia ao Pacaembu. A minuciosa preparação para a inauguração continuava:

\begin{abstract}
A Diretoria Geral dos Esportes do Estado de São Paulo, sob a gestão esclarecida do sr. tenente Sylvio Magalhães Padilha, elaborou, com inteiro acerto, o programa das festas inaugurais do Estádio do Pacaembu, certamente uma das maiores realizações do programa social-esportivo que caracteriza as atividades do Estado Novo na construção de um Brasil maior e melhor.(...) o ato inaugural da grande obra, que é o estádio Municipal de S. Paulo, destinado a marcar um acontecimento decisivo na história da educação física nacional. ${ }^{46}$
\end{abstract}

Dizia-se estar diante uma nova era esportiva, assim cabia preparar um desfile inaugural majestoso, consoante com as dimensões do Pacaembu e com 
a força que o regime Vargas acreditava possuir. E a primeira instrução vinha ao encontro de muito daquilo que o regime e seus ideólogos defendiam:

Visando premiar os que merecidamente se esforçarem para o realce do desfile, a DEESP, instituirá prêmios às representações tanto do interior como da capital, e civis ou militares que melhor satisfizerem os seguintes requisitos: a) disciplina; b) apresentação de uniforme; c) atitude em marcha ou parada; d) respeito de conjunto. (...)

Os chefes de cada uma das representações são os responsáveis diretos por elas.

Dizendo respeito às representações, é conveniente ressaltar da necessidade da presença de todas as modalidades esportivas que cada uma tenha e bem assim os seus respectivos uniformes cabendo a cada uma a iniciativa de melhor apresentação... ${ }^{47}$

Dessa forma, entre as numerosas e detalhadas etapas dessa cerimônia de inauguração, que estava dividida em doze partes, destacaremos dois desses momentos. Numa etapa - chamada Bandeira Nacional, trazida do Rio de Janeiro - temos:

No dia 27 de abril, chegará a S. Paulo uma Bandeira Nacional, conduzida por entre as cidades da estrada de rodagem Rio-S. Paulo, e que é oferecida pelo Fluminense F. C., e do seu Estádio enviada como homenagem ao $1^{\circ}$ Estádio construído no Brasil, ao Estádio do Pacaembu. Segundo instruções particulares enviadas aos prefeitos das cidades citadas, será essa bandeira recebida em cada uma delas com festejos cívicos. Os detalhes da oferta, da vinda e demais solenidades dessa entrega, serão publicadas oportunamente. ${ }^{48}$

Além da força simbólica da bandeira nacional, inclusive num momento político em que era a única bandeira que poderia ser utilizada, esse primeiro passo do desfile de abertura tinha o objetivo de envolver não apenas a cidade de São Paulo, mas os outros lugares do país, como a capital do Brasil, o Rio de Janeiro, além das cidades que separam o Rio da capital paulista. Em cada uma das cidades em que a bandeira passasse, deveriam ser organizadas manifestações também comemorando-se o grande feito de São Paulo, sempre com a

47 Instruções da diretoria de esportes. O Estado de São Paulo, 09 abr. 1940, p. 6. 48 Id. 
referência de que este, na verdade, era próprio do "Brasil novo", que estava sendo construído pelo regime ditatorial, juntamente na busca do "homem novo". A outra das etapas era a do Juramento do Esportista:

Ao comando do encarregado geral de - "Esportistas: frente para a Tribuna Oficial", todos se voltarão à frente pela esquerda para aquela tribuna e sempre imóveis. Em seguida haverá os comandos: "Para o juramento do Esportista! Preparar! a este comando todos os que estiverem no campo, com exceção das bandeiras das representações e Nacional, levantando o braço direito para a frente até a altura do ombro..."Incorporando-me à falange esportiva juro dedicar-me com devotamento - lealdade e disciplina praticando e difundindo - a educação física e esportiva colaborando com todas as minhas energias para fazer do Brasil uma nação forte - respeitar os regulamentos que nos regem - e cumprir rigorosamente as ordens que receber - de executar mesmo com sacrifício dos próprios interesses - e com espírito alegre e cavalheirismo - concorrendo para a formação de nosso tipo - de corpo e alma - tão viris quanto nobres - pela glória - defesa - e dignidade - do Esporte - e do Brasil...99

Esse juramento ressaltava, dentro de todo o ritual, como o esporte e as atividades físicas, em geral, deveriam estar a serviço do "novo homem", que construiria um Brasil forte.

Por outro lado, a festa foi organizada para emocionar e a inauguração do Pacaembu foi um grande ato cívico-político de amplitude nacional, ao envolver desde o presidente da República até os interventores, passando por delegações estrangeiras e por representantes de inúmeras cidades de São Paulo e de outros Estados. Ao provocar a emoção, a cerimônia pretendeu mostrar a força de um regime, consubstanciada na própria construção monumental, além de materializar concepções como ordem, harmonia, unidade e beleza. ${ }^{50}$

49 Id.

50 Nesse sentido, é possível fazer uma analogia com as manifestações políticas realizadas na Alemanha nazista - guardando, obviamente, as devidas distâncias de experiências contemporâneas, mas historicamente distantes. Alcir Lenharo fala desse momento na Alemanha, produzindo a política enquanto espetáculo: "Qualquer ocasião podia ser utilizada como recurso de mobilização popular nas ruas e de envolvimento político das massas (...)A chave da organização dos grandes espetáculos era converter a própria multidão em peça essencial dessa mesma organização. Nas paradas e desfiles pelas ruas ou nas manifestações de massa, estáticas, em praças públicas, a multidão se emocionava de maneira contagiante.(...)" Cf.: LENHARO, Alcir. Nazismo - O triunfo da vontade. 2. ed., São Paulo: Ática, 1990, p. 39. 
Após o longo desfile, quando todos os dez mil esportistas uniformizados estavam dentro do campo, simetricamente acomodados, de frente para a tribuna de honra, o prefeito de São Paulo, Prestes Maia, pronunciou o seu discurso:

...A nossa praça de esportes é, senhor Presidente, a afirmação de um programa construtivo. Tendo-o recebido em início, pusemos na sua ampliação e na sua conclusão o nosso melhor empenho. E, assim, como restituímos as administrações passadas a honra de sua iniciativa, reivindicamos, para a presente, a glória de sua execução, na grandiosa escala e moldura, que hoje se descortina... ${ }^{51}$

Depois do discurso do prefeito paulistano, enquanto continuação da festa do Pacaembu, viria a fala - de improviso, segundo a reportagem do Estado - do presidente Vargas:

...Este monumento consagrado à cultura física da mocidade, em pleno coração da capital paulista, é motivo de justo orgulho para todos os brasileiros e autoriza aplaudir merecidamente a administração que o construiu.

As linha sóbrias e belas da sua imponente massa de cimento e ferro, não valem, apenas, como expressão arquitetônica, valem como uma afirmação da nossa capacidade e do esforço criador do novo regime na execução do seu programa de realizações.

É ainda, e sobretudo, este monumental campo de jogos desportivos uma obra de sadio patriotismo, pela sua finalidade de cultura física e educação cívica.

Agora mesmo assistimos ao desfile de dez mil atletas, em cujas evoluções, havia a precisão e a disciplina, conjugadas no simbolismo das cores nacionais. Diante dessa demonstração da mocidade forte e vibrante, índice eugênico da raça, - mocidade em que confio e que me faz orgulhoso de ser brasileiro - quero dizer-vos:

Povo de S. Paulo!

Compreendestes perfeitamente que o Estádio do Pacaembu é obra vossa e para ela contribuístes com o vosso esforço e a vossa solidariedade. E compreendestes ainda que este monumento é como um marco da grandeza de São Paulo a serviço do Brasil.

Declaro, assim, inaugurado o Estádio do Pacaembu. ${ }^{52}$

51 Inaugurado o Estádio Municipal do Pacaembu. O Estado de São Paulo, 28 abr. 1940, p. 8. 52 Id. 
Vargas apenas reafirmou, com seu discurso, uma concepção recorrente na época acerca do papel das atividades físicas e da necessidade de amplos espaços para manifestações de caráter cívico-político e enfatizar, na sua perspectiva, o papel de São Paulo nesse novo momento da história do país.

Porém, por mais que o poder público tenha projetado e construído o Estádio do Pacaembu enquanto um monumento para as grandes manifestações cívicas, para os torcedores este estádio significou um espaço muito especial, onde se manifestava a paixão pelo futebol; e, na lembrança de muitos deles, ficaram retidas as imagens de grandes jogos, dos times e jogadores. ${ }^{53}$

Dessa maneira, não foram as festas cívicas realizadas no Pacaembu as responsáveis pelos momentos de maior emoção vividos no estádio. A vinda do jogador Leônidas da Silva para jogar em São Paulo, no São Paulo F. C., por exemplo, fez reavivar, ainda mais, o gosto pelo futebol na cidade. Quando a sua contratação foi efetivada junto ao Flamengo do Rio de Janeiro, e a notícia da confirmação chegou aos torcedores do São Paulo, estes começaram a preparar uma festa de recepção para o grande jogador do selecionado de futebol, a maior figura dentro da Copa de 38 na França. A chegada do ex-jogador do Flamengo foi uma das maiores manifestações populares que a cidade conheceu.

Não resta dúvida de que a ligação entre a monumentalidade do estádio do Pacaembu e a vinda de Leônidas exprimiam o sentido de uma nova era para o futebol em São Paulo. O Estádio pensado pelo poder público e pelos teóricos da Educação Física como um espaço para a formação física, moral e cívica da juventude, tornou-se, rapidamente, palco de grandes partidas de futebol, com platéias cada dia maiores e mais apaixonadas.

Assim, é possível considerar a idéia - e posterior construção - do Estádio Municipal do Pacaembu como síntese de uma época que tinha muita preocupação com a questão do corpo do brasileiro. Mas, por outro lado, a sua construção se deu no seio de um regime autoritário, que buscou de maneira incessante inúmeras formas de legitimação, como a construção de grandes obras arquitetônicas com um forte sentido simbólico. O Estádio surgiu nesse contexto, mas se tornou efetivamente um templo do futebol, inspirando e projetando sua trajetória na memória da cidade. Conhecer os caminhos que levam até o Pacaembu permite compreender o significado das atividades físicas em São Paulo, a partir dos anos 1930.

53 Nas lembranças de Chico Mendes, torcedor do Corinthians, ao se referir ao Pacaembu, só existe espaço para o futebol. "O Pacaembu deu uma nova vida ao futebol de São Paulo. Assim com depois o próprio...lá o do São Paulo e o Maracanã também. O Pacaembu tinha uma coisa: era aconchegante." Assim, as grandes festas cívicas, motivo maior do Estádio, foram esquecidas. 


\section{Futebol e Nação}

Assim, a conjugação de inúmeros eventos, com destaque à participação do selecionado brasileiro de futebol na Copa da França e à construção do Estádio do Pacaembu, o futebol tornou-se um forjador da unidade nacional. As características desse fenômeno social - que há muito havia ultrapassado a condição de uma mera atividade esportiva - foram decisivas para que o jogo da bola fosse um dos pólos utilizados para a construção da idéia de nação. E como se viu, o papel da imprensa - dos jornais e do rádio - foi muito importante. Daí a derrota na Copa de 1938 ter sido a derrota da nação, esta sim sendo prejudicada e não uma simples equipe de futebol. Os laços entre futebol e nação eram estreitados, tornando-se presentes até hoje. 